\title{
Perbedaan Kadar Leptin pada Anak yang Menderita Infeksi Dengue
}

\author{
Anggia Farrah Rizqiamuti, Sri Endah Rahayuningsih, Dedi Rachmadi, Rachmat Budi \\ Departemen Ilmu Kesehatan Anak, Fakultas Kedokteran, Universitas Padjadjaran, Rumah Sakit Dr. \\ Hasan Sadikin, Bandung
}

\begin{abstract}
Latar belakang. Infeksi dengue merupakan infeksi akut yang dapat mempengaruhi kadar leptin. Perbedaan spectrum klinis infeksi dengue menyebabkan perbedaan kadar interleukin-6 (IL-6) dan tumor necrosis factor- $\alpha$ (TNF- $\alpha)$.

Tujuan. Mengetahui perbedaan kadar leptin pada anak yang menderita infeksi dengue.

Metode. Penelitian analitik dengan rancangan potong lintang. Subjek penelitian adalah pasien DB, DBD, dan SSD (pascasyok) yang memenuhi kriteria klinis dan telah dibuktikan melalui pemeriksaan serologis. Analisis data menggunakan uji Kruskal Wallis dan Mann-Whitney untuk menentukan perbedaan kadar leptin pada DB dengan DBD dan SSD.

Hasil. Pasien infeksi dengue 48 anak terdiri dari 27 DB, 11 DBD, dan 10 SSD. Terdapat perbedaan bermakna kadar leptin antara DB dengan DBD, dan SSD p=0,002. Rerata kadar leptin pada DD 703,4 (374,1-3616,7), DBD 2.172 (554,3-16631,1), dan SSD $1.321(250,5-4.714,6) . \mathrm{ng} / \mathrm{mL}$ Kadar leptin DBD lebih tinggi dibandingkan dengan DD ( $<<0,001)$, namun kadar leptin antara DBD dan SSD tidak berbeda bermakna $(\mathrm{p}=0,132)$ dan kadar leptin antara SSD (postsyok) dan DD tidak berbeda bermakna $(\mathrm{p}=0,158)$.

Kesimpulan. Kadar leptin pada DBD lebih tinggi dibandingkan dengan DD, sedangkan kadar leptin antara DBD dan SSD (postsyok) tidak berbeda. Sari Pediatri 2013;15(1):1-4.
\end{abstract}

Kata kunci: demam dengue, demam berdarah dengue, sindrom syok dengue, leptin

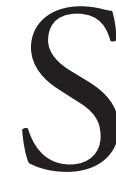

alah satu mekanisme imun saat terjadi infeksi akut, yaitu terjadi peningkatan sintesis IL-6 dan TNF- $\alpha .{ }^{1}$ Interleukin-6 dan TNF- $\alpha$ akan menstimulasi jaringan adiposa untuk mensintesis leptin., ${ }^{2,3}$ Semakin berat proses infeksi,

\footnotetext{
Alamat korespondensi:

Dr. Sri Endah Rahayuningsih, dr.,Sp.A(K). Departemen Ilmu Kesehatan Anak, Fakultas Kedokteran UNPAD/RSHS. Jl. Pasteur 38 Bandung 40163, Telp. (022) 2035957, Fax. (022) 2034426. E-mail: endah. perkani@gmail.com
}

semakin tinggi kadar leptin yang dihasilkan. ${ }^{2}$ Penelitian Arnalich dkk ${ }^{4}$ tahun 1990 menyatakan bahwa kadar leptin tertinggi didapatkan pada pasien sepsis dan syok. Kadar leptin kembali normal setelah pasien mengalami perbaikan. ${ }^{4}$

Penelitian yang dilakukan terhadap pasien keganasan didapatkan peningkatan kadar leptin setelah dilakukan pemberian TNF- $\alpha .{ }^{5}$ Namun, penelitian Bernstein $\mathrm{dkk}^{6}$ menyatakan bahwa kadar IL-6 dan TNF- $\alpha$ tidak sebanding dengan derajat keparahan sakit. Penelitian kami menyatakan bahwa 
kadar leptin pada pasien sepsis berat yang selamat, kadarnya lebih tinggi apabila dibandingkan dengan yang meninggal. ${ }^{6}$

Infeksi virus dengue merupakan infeksi akut yang dapat menyebabkan perubahan kadar leptin. Virus ini ketika bereplikasi dalam monosit dan makrofag menyebabkan sintesis IL-6 dan TNF- $\alpha$ meningkat yang selanjutnya merangsang jaringan adiposa untuk mensintesis leptin. ${ }^{7}$

Penelitian sebelumnya menyatakan bahwa kadar IL-6 dan TNF- $\alpha$ lebih tinggi pada demam berdarah dengue (DBD dan sindrom syok dengue (SSD) apabila dibandingkan dengan demam dengue (DD). ${ }^{8}$ Sebaliknya penelitian Huang $\mathrm{dkk}^{10}$ menyatakan bahwa kadar IL-6 dan TNF- $\alpha$ lebih tinggi pada DD dibandingkan dengan DBD. Tujuan penelitian ini adalah menentukan perbedaan kadar leptin pada DD dengan DBD, dan SSD.

\section{Metode}

Penelitian observasional analitik dengan rancangan potong lintang dengan data diambil secara konsekutif. Berdasarkan tingkat kepercayaan $95 \%$, power test $80 \%$, didapatkan besar sampel 48 subjek, terdiri dari 27 DD, 11 DBD, dan 10 SSD. Data subjek dikumpulkan berdasarkan anamnesis, pemeriksaan fisis, dan laboratorium yaitu pemeriksaan IgG/IgM anti dengue dan leptin. Subjek penelitian adalah pasien DD, DBD, dan SSD yang dirawat di ruang perawatan anak RS Dr. Hasan Sadikin, Bandung, RS Ujung Berung, dan RS
Cibabat periode Desember 2011 sampai Mei 2012. Kriteria inklusi penelitian, yaitu 1) Pasien DD, DBD dan SSD (pascasyok 12 hingga 24 jam), 2) Usia 6-14 tahun, 3). Hari sakit ke-5-7 yang telah terbukti dengan pemeriksaan imunoglobulin $\mathrm{G}(\mathrm{Ig} \mathrm{G}+)$ / imunoglobulin $\mathrm{M}(\mathrm{IgM}+)$ atau salah satunya positif.

Analisis statistik menggunakan analisis nonparametrik dengan metode Kruskal Wallis untuk menentukan kadar leptin pada DD, DBD, dan SSD, sedangkan perbedaan kadar leptin antara masingmasing diagnosis dianalisis menggunakan uji statistik Mann-Whitney. Analisis data menggunakan program SPSS for windows versi 17.0. Penelitian dilaksanakan setelah mendapat persetujuan Komite Etik Penelitian Kesehatan Fakultas Kedokteran Universitas Padjajaran RS Dr. Hasan Sadikin Bandung.

\section{Hasil}

Duapuluh tujuh subjek DD, terdiri dari 12 laki-laki dan 15 perempuan, 11 DBD terdiri dari 5 laki-laki dan 6 perempuan, dan 10 SSD terdiri dari 4 laki-laki dan 6 perempuan. Subjek dikelompokkan berdasarkan hasil uji serologis dengue, dengan hasil DD $\operatorname{IgG}(+) /$ $\operatorname{IgM}(+) 19$ orang, $\operatorname{IgG}(+) / \operatorname{IgM}(-) 8$ orang, pasien $\mathrm{DBD}$ $\operatorname{IgG}(+) / \operatorname{IgM}(+) 6$ orang, $\operatorname{IgG}(+) / \operatorname{IgM}(-) 4$ orang, IgG(/) $\operatorname{IgM}(+) 1$ orang, sedangkan SSD $\operatorname{IgG}(+) / \operatorname{IgM}(+) 9$ orang, $\operatorname{IgG}(+) / \operatorname{IgM}(-) 1$ orang. Empatpuluh enam subjek memiliki status gizi baik (Tabel 1).

Berdasarkan analisis varians menggunakan metode Kruskal Wallis, didapatkan perbedaan bermakna kadar

Tabel 1. Karakteristik subjek penelitian

\begin{tabular}{lccc}
\hline Variabel & \multicolumn{3}{c}{ Diagnosis } \\
\cline { 2 - 4 } & $\begin{array}{c}\mathrm{DD} \\
(\mathrm{n}=27)\end{array}$ & $\begin{array}{c}\mathrm{DBD} \\
(\mathrm{n}=11)\end{array}$ & $\begin{array}{c}\text { SSD (pascasyok) } \\
(\mathrm{n}=10)\end{array}$ \\
\hline Usia (tahun) & $9,78(2,517)$ & $10,24(2,166)$ & $10,5(2,41)$ \\
$\quad$ Rerata (SB) & 10,00 & 11,0 & 11,5 \\
Median & $5-13$ & $6-12$ & $6-13$ \\
Rentang & & & 4 \\
Jenis kelamin & 12 & 5 & 6 \\
Laki-laki & 15 & 6 & 9 \\
Perempuan & & & \\
Uji Serologis & 19 & 6 & 0 \\
IgG(+)/IgM(+) & 8 & 4 & \\
IgG(+)/IgM(-) & 0 & 1 & \\
IgG(-)/IgM(+) & & & \\
\hline
\end{tabular}


leptin antara DD, DBD, dan SSD p=0,002 (Tabel 2). Berdasarkan analisis dengan menggunakan uji Mann-Whitney diperoleh hasil bahwa tidak terdapat perbedaan bermakna antara DD dan SSD $\mathrm{p}=0,158$; antara DBD dan SSD $\mathrm{p}=0,132$; sedangkan kadar leptin antara DD dan DBD bermakna $\mathrm{p}<0,001$.
DBD tidak berbeda bermakna, sehingga keadaan tersebut mungkin menyebabkan kadar leptin tidak berbeda bermakna. Hasil kadar leptin yang tidak bermakna antara SSD dan DD tidak dapat dijelaskan secara aspek imunologis. Keterbatasan penelitian kami adalah kadar IL-6 dan TNF- $\alpha$ yang dapat memicu

Tabel 2. Perbandingan kadar leptin berdasarkan klasifikasi diagnosis

\begin{tabular}{lcccc}
\hline $\begin{array}{l}\text { Kadar leptin } \\
(\mathrm{ng} / \mathrm{mL})\end{array}$ & $\begin{array}{c}\text { DF } \\
(\mathrm{n}=27)\end{array}$ & $\begin{array}{c}\text { DHF } \\
(\mathrm{n}=11)\end{array}$ & $\begin{array}{c}\text { DSS (pasca syok) } \\
(\mathrm{n}=10)\end{array}$ & Nilai $^{*}$ \\
\hline Median (rentang) & $703,4(374,1-3616,7)$ & $2.172(554,3-16631,1)$ & $1.321(250,5-4.714,6)$ & 0,002 \\
\hline
\end{tabular}

Ket:*) Berdasarkan uji Kruskal Wallis

\section{Pembahasan}

Data yang didapatkan dari subjek di ruang perawatan anak Dr. Hasan Sadikin Bandung, RS Ujung Berung, dan RS Cibabat selama periode pemeriksaan, didapatkan 27 pasien DD, 11 pasien DBD, dan 10 pasien SSD (pascasyok. Perbedaan jumlah subjek tersebut disebabkan karena pengelompokan berdasarkan hasil uji serologis yang memenuhi kriteria inklusi. Setelah dianalisis dengan uji statistik MannWhitney didapatkan kadar leptin pada DBD lebih tinggi dibandingkan dengan DD.

Monosit dan makrofag merupakan target utama virus dengue selama proses infeksi terjadi. ${ }^{4}$ Virus dengue yang bereplikasi dalam sel mononuklear selanjutnya akan merangsang sintesis TNF- $\alpha$ dan IL-6. ${ }^{1,2}$ Tumor necrosis factor- $\alpha$ dan IL-6, selanjutnya akan merangsang jaringan adiposa untuk mensintesis leptin. ${ }^{1,2}$ Hasil penelitian kami menunjukkan bahwa kadar leptin pada DBD lebih tinggi dibandingkan dengan DD. Peningkatan kadar leptin tersebut disebabkan karena subjek DBD kemungkinan pernah mengalami infeksi serupa sebelumnya yang mungkin disebabkan oleh serotipe virus yang berbeda. Hal tersebut menyebabkan virus dengue yang menginvasi sel mononuklear tidak dapat dimusnahkan oleh mekanisme imunitas pasien, sehingga kadar IL- 6 dan TNF- $\alpha$ dihasilkan lebih tinggi dibandingkan dengan pasien yang belum pernah mengalami infeksi serupa sebelumnya. ${ }^{11}$

Hasil penelitian kami menunjukkan kadar leptin pada SSD tidak berbeda bermakna dengan DBD. Pemeriksaan kadar leptin dilakukan pada saat 12-24 jam setelah syok teratasi, sehingga kadar leptin belum menurun karena waktu paruh leptin sekitar 75 menit. ${ }^{2}$ Kadar IL-6 dan TNF- $\alpha$ pada SSD maupun sintesis leptin tidak diperiksa sehingga diperlukan penelitian lebih lanjut. Disimpulkan bahwa kadar leptin pada DBD lebih tinggi dibandingkan dengan DD, sedangkan kadar leptin antara SSD dan DBD tidak berbeda.

\section{Daftar pustaka}

1. Li J, Li F, Zhao A. Inflamation and leptin. Drug Discovery Today 2006;3:387-92.

2. Johnson W, Finck. Tumor necrosis factor alpha and leptin: two players in an animals metabolic and immunologic responses to infection .J Anim Sci 2012;79:118-27.

3. Lam QL, Lu L. Role of leptin in immunity. Cell Mol Immunol Review 2007;4:1-9.

4. Arnalich F, Lopez J, Codoseo R, Jimenez M, Modero $\mathrm{R}$, Montel C. Relationship of plasma leptin to plasma cytokines and human survival in sepsis and septic shock. Infect Diss J 1999;180:908-11.

5. Zumbach MS, Brehme MWJ, Wahl P, Stremmel W, Ziegler R, Nawroth PP. Tumor necrosis factor increases serum leptin levels in human. J Clin Endocrinol Metab 1997;82:4080-7.

6. Bernstein SR, Liemin J, Tauchmi LR. Plasma leptin levels are increased in survivor of acute sepsis associated loss of diurnal rythm in cortisol and leptin secretion. J Clin Endocrinol Metab 2008;83:280-3.

7. Lei HY, Yeh TM, Liu HS, Sin YS, Chen SH, Liu CC. Immunopathogenesis of dengue virus infection.J Biomed Sci 2001;8:377-88.

8. Nguyen TH, Lei HY, Nguyen TL, Lin YS, Huang KL, Le BL, dkk. Dengue hemorrhagic fever in infants: a study of clinical and cytokine profiles. J Infect Dis 2004;189:221-32. 
9. Salgado DM, Garzon M, Vega R, Panqueba C, Narvaez CF, Rodriguez JA. Pattern of serum cytokines in children with dengue hemorrhagic fever in neiva. Revista Facultad de Salud 2010;2:21-9.

10. Huang YH, Lei HY, Liu HS, Lin YS, Liu CC, Yeh TM. Dengue virus infects human endothelial cells and induces IL-6 and IL-8 production. Am J Trop Med 2000;63:71-5.

11. Chakravarti A, Kumaria R.Circulating levels of tumour necrosis factor alpha and interferron gamma in patients with dengue and dengue haemorrhagic fever during an outbreak.Indian J Med Res 2006:25-30. 